\title{
THE HIDDEN COSTS OF PRIVATE ACTIVITY TAX-EXEMPT BONDS
}

\author{
Matthew R. Marlin ${ }^{*}$
}

\begin{abstract}
A growing body of literature indicates that the tax-exempt bond market is subject to regional segmentation by states. This assumption implies that there are in fact 50 separate tax-exempt bond markets, each finding its own equilibrium yield level according to market conditions in its respective state. If this is indeed the case, then those states that issued large volumes of private activity tax-exempt bonds in the belief that they represented a costless subsidy were in error. This study shows that the increased supplies of private activity tax-exempt debt issued in the states resulted in significantly higher interest rates for all types of debt.
\end{abstract}

\section{INTRODUCTION}

During the late 1970s and early 1980s, local governments and their agencies issued billions of dollars of tax-exempt municipal bonds to subsidize private investment. Referred to as private activity bonds (PABs), tax-exempt finance is popular with borrowers because, all else being the same, tax-exempt financing results in lower interest rates. ${ }^{1}$ Lenders prefer tax-exempt financing because (long-term) tax-exempt yields generally exceed the after-tax yields on comparable taxable bonds. ${ }^{2}$ This study, however, examines the costs that fall on the third party involved in tax-exempt finance, the local governments that serve as a conduit between the tax-exempt borrowers and lenders. Despite the advantages to borrowers and lenders, tax-exempt finance of private capital cannot take place unless the local government is willing to issue the bonds.

Local governments have historically been very willing to issue tax-exempt bonds on behalf of private businesses, primarily because they are viewed as being without cost to the locality that issues the bond (Marlin 1989). First, the tax exemption that produces the low borrowing cost for the firm is a cost to the federal (and state) government. Second, nearly all tax-exempt bonds issued on behalf of private businesses are revenue bonds, secured only by the revenue-generating capacity of the firm that receives the loan. The issuing community therefore undertakes no default or credit risk. Third, all administrative costs are paid by the firm borrowing the funds through an administrative fee added to the interest rate. In short, PABs are a popular subsidy from the local government perspective be-

\footnotetext{
*Associate Professor of Economics, Duquesne University
} 
cause they appear to allow the subsidization of local businesses with someone else's money.

Prior to 1986, PABs were the most popular subsidy used by local governments. Believing that the use of PABs represented a free lunch, state and local governments used the bonds to promote industrial development (IDBs), build single- and multi-family housing projects, build quasi-public infrastructure such as airports and parking garages, and finance a number of other projects. PABs are generally issued by local governments, although the authority to issue them actually rests with state governments. While state laws vary with respect to the ways that PABs may be used, most states have been quite liberal in what they will allow. As a result, PAB volume reached over $\$ 99$ billion in 1985 , an amount that exceeded the total dollar volume of traditional "public" use tax-exempt bonds in that year (Poterba 1989).

Increasing volumes of private use tax-exempt debt and perceived abuses in the way it was used motivated Congress to pass federal legislation restricting the use of PABs. The Tax Equity and Fiscal Responsibility Act of 1982 (TEFRA), the Deficit Reduction Act of 1984, and the Tax Reform Act of 1986 each included increasingly restrictive provisions limiting the issue of PABs. As a result, preliminary estimates indicate that $\mathrm{PAB}$ volume fell to about $\$ 1$ billion in $1987 .{ }^{3}$ Since that time, however, numerous groups representing potential tax-exempt borrowers, lenders, and state and local governments have lobbied continuously to ease the restrictions on private use tax-exempt bonds (Marlin 1989).

Local governments that advocate a return to more liberal PAB policies may be basing their advocacy on an incorrect evaluation of their costs. A growing body of literature has suggested that the tax-exempt bond market is subject to regional segmentation, and that an increased supply of tax-exempt debt in a region will push down its price and result in higher yields. If this is indeed the case, then local governments that issue increased volumes of private tax-exempt debt may be paying a price in the form of higher tax-exempt yields on all debt, both public and private. The purpose of the present study is to examine this issue and analyze the relationship between regional (state) PAB volume and tax-exempt bond yields.

This paper is organized into four additional sections. Section II briefly describes the theory of regional segmentation and reviews prior studies. A hypothesized relationship between regional PAB supplies and tax-exempt bond yields is then developed. Section III develops and describes a model of the taxexempt bond market that can be used to test the hypothesized relationship. Section IV presents empirical tests of the hypothesized relationship, using state volumes of private activity tax-exempt bonds from 1983 through 1986. Section V 
is reserved for a summary and some conclusions regarding the implications of regional segmentation and the use of private activity bonds.

\section{THE THEORY OF REGIONAL SEGMENTATION}

\section{The Theory}

For a number of reasons, the demand for tax-exempt bonds is generally restricted to the region where the bonds are issued. First, the regional supply of tax-exempt bonds issued by state and local governments is characterized by a large number of relatively small, unregistered and unrated bonds issued by numerous infrequent suppliers. These bonds are not subject to mandatory disclosure and periodic reporting requirements. Information about local issues is therefore costly and decays as distance from the issuer increases. The small size and lack of ratings limit demand to those borrowing within the issuing vicinity who have both the information about the issuer's credit worthiness and an interest in the local economy (Hendershott and Kidwell 1978; Leonard 1983; Kidwell, Koch, and Stock 1984).

A second factor that restricts demand to the issuing region is that most states allow a state income tax exemption for interest earned on securities issued within their borders, but do not allow such an exemption for bonds issued in other states. All else being the same, this situation leads to higher net yields and greater demand for in-state bond issues.

Third, many states have "pledging requirements" that require institutions holding state or local government deposits to collateralize these deposits by buying tax-exempt bonds issued within the same state or local jurisdiction (Leonard 1983; Kidwell, Koch, and Stock 1984, 1987). One further reason to expect the market to be dominated by local investors is the existing restrictions on commercial banks that limit their ability to engage in interstate banking. Because banks have been a major purchaser of tax-exempt bonds over the years, these limitations contribute to the regionalization of the market. ${ }^{4}$

The above arguments suggest that small tax-exempt bonds issued in one state will not be perfect substitutes for bonds issued in other states. This theory of "regional segmentation" implies that increased regional (state) supplies will result in higher yields in that region that will not be "arbitraged away" by investors in different states. As a result, comparable bonds issued in different states will carry different yields. Conversely, increased demand within the region will result in lower yields, as local investors will not easily be able to pursue possibly higher tax-exempt returns in other states. 
The large bond issues of major cities (and large state issues) are not as likely to be subject to regional segmentation as are small bond issues. Their market tends to be more national, and they are generally purchased by underwriting syndicates located in the country's financial centers. As a consequence, even though a large portion of these issues do find their way back into the state where they were issued (Hendershott and Kidwell 1978; Kidwell, Koch, and Stock 1984, 1987), the initial purchasers of such bond issues are often located outside the state of issue. Thus, the arguments for regional segmentation apply more to small, rather than large bond issues (the findings of other authors confirming this point are discussed below). However, because PABs are generally limited by statute to a maximum of $\$ 10$ million, they therefore will be subject to the above outlined conditions necessary for regional segmentation.

\section{Prior Studies}

Hendershott and Kidwell (1978) were the first to demonstrate that the regional supply of tax-exempt bonds has significant impacts on regional interest rates, and that the tax-exempt market is subject to regional segmentation. The authors empirically evaluated this premise by examining the supply side of the market using quarterly data for Indiana from 1972 through 1974. The authors used the volume of both public and private use Indiana bonds as a percentage of national volume to measure relative supply. Their results indicated that increased supplies of Indiana bonds were associated with higher yields in that state.

A few years later, Kidwell and Trzcinka (1983) extended the analysis to show that the interest rate effects of the New York City debt crisis in 1975 remained geographically localized. This study used daily data on individual issues in 1974 and 1975 to show that yield increases associated with the New York City fiscal crisis of 1975 were primarily confined to the city itself. In contrast to the two studies cited above, Leonard (1983) examined the demand side of the market using data from 1973 through 1976. He concluded that variations in demand due to the perceived riskiness of issuers in different regions and the presence of pledging requirements were associated with variations in returns across different states-further evidence of the existence of segmentation.

Using bond data from 1980, Kidwell, Koch, and Stock (1984, 1987; hereafter referred to as Kidwell et al.) showed that variations in state tax-exempt bond yields were, as expected, negatively associated with state income tax rates and pledging requirements. The former relationship exists because high state income tax rates increase the demand for in-state bonds, thus increasing bond prices and depressing bond yields. The latter relationship reflects the fact that pledging 
requirements also increase the demand for in-state bonds by requiring commercial banks to hold a certain volume of locally issued bonds.

Interestingly, Kidwell et al. (1987) found that segmentation effects existed with long term bonds (ten years or greater), but not with short-term bonds (one year). In addition, although they found that segmentation existed for their sample as a whole, it did not exist among the bonds in their sample that were greater than $\$ 15$ million. This finding strongly suggests that segmentation may exist with the use of PABs. PABs generally carry maturities ranging from 10 to 20 years, and, in almost all cases, they are restricted by statute to less than $\$ 10$ million (Statistics on Income Bulletin, various issues).

Applying the theory of regional segmentation to the private use of tax exempt bonds suggests the hypothesis that, all else being the same, increased supplies of PABs will result in higher tax-exempt yields in the issuing region. The following sections of this paper introduce a model, assumptions, and the data necessary to empirically test this hypothesis.

\section{MODEL SPECIFICATION, DATA, AND ASSUMPTIONS}

\section{The Model}

The model developed here follows Hendershott and Kidwell (1978) in that tax-exempt yields in a given state are hypothesized to be a function of relative bond supply and the economic strength of the issuing state. In addition, following Cluff and Farnham (1985), as the present study incorporates the 48 contiguous states, yields are also modeled as a function of the region of the country in which the bonds are issued. This reflects both regional economic strength and the fact that available information within a multi-state region is likely to be greater than information available outside the region. Finally, following Kidwell et al., the model includes a dummy variable that indicates those states that exempt some or all in-state bond interest from state income taxation. The model to be estimated is of the following form:

$$
\mathrm{Y}_{\mathrm{e}}=\mathrm{a}-\mathrm{B}_{1}(\mathrm{ECON})-\mathrm{B}_{2}(\mathrm{TAX}) \pm \mathrm{B}_{3}(\text { REGION })+\mathrm{B}_{4}(\mathrm{PABs})
$$

where $\mathrm{Y}_{\mathrm{e}}$ is the average tax-exempt yield of each state in 1986; ECON is a vector of regional (state) economic variables; TAX is a dummy variable indicating those states that exempt some or all in-state bond interest from state income taxation; REGION is a set of $0-1$ multi-state regional dummy variables; and PABs is the total per capita volume of private activity tax-exempt bonds issued in each state 
from 1983 through 1986. The expected signs are as shown in the equation; yields should be positively related to supply and negatively related to taxes and economic vitality. The sign for the regional dummies can be either positive or negative depending on which region is used as the reference point.

\section{The Data}

Prior analyses of the tax-exempt bond market have been limited by the scarcity of reliable supply data. As noted above, mandatory disclosure and periodic reporting of issues are not generally required, and this situation often results in a sample dominated by nationally oriented issues and/or issues from major population centers (Cluff and Farnham 1985). However, as a result of the Tax Equity and Fiscal Responsibility Act of 1982 (TEFRA), state and local governments have been required to report all issues of private activity tax-exempt bonds to the U.S. Treasury Department on a quarterly basis since 1983. These PAB data are reported in various issues of Statistics of Income Bulletin, published by the U.S. Treasury. As of December 1990, data for 1987 and later had not been released by the Treasury.

Ideally, the relative intensity of PAB use in different states would be measured by $\mathrm{PAB}$ volume relative to other tax-exempt debt. However, statewide data describing total tax-exempt bond activity are not available. As an alternative, the per capita volume of PABs issued by the 48 contiguous states from 1983 through 1986 is used as the measure of bond supply in the present analysis.

The use of per capita data differs from prior studies (Hendershott and Kidwell 1978; Kidwell and Trzcinka 1983; Kidwell, Koch, and Stock, 1984, 1987) that used the volume of state issues relative to total national issues as the measure of relative supply. A problem with the previously used measure is that more populous states will naturally have larger relative volumes than smaller states. In contrast, the per capita measure captures the relative intensity of PAB use and potential "saturation" of the state market.

For the entire four-year period (1983 through 1986), per capita values ranged from a low of $\$ 292$ in Idaho to a high of $\$ 2,370$ in Delaware, with a mean of $\$ 891$. On a yearly basis, PABs accounted for about half of all new tax-exempt bond issues from 1983 through 1985. Their volume fell to about 10 percent of the total in 1986 as a result of the provisions of the Tax Reform Act of 1986, which severely restricted their use. Annual activity peaked in 1985 at an average per capita volume of $\$ 417$.

The logged value of the per capita volume of PABs is used in the estimating model. Using the log of the variable is preferred to using linear values because the tax-exempt yield is bounded above by the level of the taxable yield: This 
specification allows the tax-exempt yield to increase at a decreasing rate as per capita $\mathrm{PAB}$ volume increases. If regional segmentation exists in the private use tax-exempt bond market, the coefficient of the PAB variable will be positive and significantly different from zero.

Relevant economic factors that influence yields include regional income, debt burden, tax effort, and other indicators of economic well-being (Hendershott and Kidwell 1978; Leonard 1983; Cluff and Farnham 1985). Hendershott and Kidwell (1978) suggest that higher regional incomes increase the demand for bonds, thus increasing prices and decreasing yields. An alternative explanation is that a stronger economy implies reduced risk and therefore lower yields. Regardless of the mechanism, however, there should be an inverse relationship between economic strength and yields.

The above discussion points out the problem of isolating the influence of demand and supply in bond yield determination. Similar to the models used by other authors, the current specification is not able to completely separate the two. Although the level of economic vitality controls for some variation in demand, the model implicitly assumes that, given demand, it is the variation in PAB supply that is determining yields.

Although a number of measures of economic vitality were tried in the present estimating equation, only the percentage change in per capita Gross State Product (GSP) from 1983 to 1986 showed a significant correlation with yield levels when all variables were entered at the same time. The most likely explanation is the high degree of correlation between this variable and the other variables examined: per capita debt, tax effort, employment and unemployment rates, ownsource revenue, and population change. Accordingly, GSP alone is used in the estimating equations to measure the economic strength of the different states. GSP data for all the states are compiled by the U.S. Department of Commerce and published in the Survey of Current Business (Renshaw, Trott, and Friedenberg 1978).

As indicated above, binary dummy variables were used to indicate both the region of the country where the bonds were issued and the state policies toward the taxation of interest on in-state municipal bonds. The number of multi-state regions was reduced to four (Northeast (D NE), Midwest (D MW), South (D S), and West) in order to minimize the loss of the available degrees of freedom in a data set that includes only 48 cases. The tax policy of each state was taken from Kidwell et al. (1987). In all, 36 of the contiguous states exempt all or some instate interest while taxing out-of-state interest. An additional dummy, not reported in the results, was necessary to account for the atypically high yield in Oklahoma due to the collapse of oil prices.

Finally, average tax-exempt yields for the 48 contiguous states in 1986 were obtained from the Public Securities Association. The averages were derived from 
more than 8,000 bonds issued in that year. The number of bonds per state ranged from a low of 19 in Wyoming to a high of 753 in California. Ideally, a test of the impact of PABs on yields would make use of separate indices of public and private tax-exempt yields rather than the "blended" rates that are reflected in the PSA data. However, such indices are not readily available, and the PSA data will be used with the understanding that they represent a workable, rather than an optimal, measure of yields.

\section{Assumptions}

The validity of the above model relies on three assumptions. First, if private and public use tax-exempt bonds are substitutes in investor portfolios, increased supplies of PABs will influence all regional tax-exempt yields. If they are not substitutes, increased PAB supplies will influence only PAB yields. As noted, yield data comprised of both public and private yields is used to test the hypothesis. The hypothesized correlation between overall yields and PAB supplies must therefore be based on the assumption of substitution in investor portfolios.

Despite the importance of substitutability, no direct evidence exists to either support or reject the claim. In the most thorough examination of the PAB market to date, Zimmerman (1991, 74-76) implicitly accepts the assumption that public and private use bonds are substitutes in investor portfolios as he describes the demand for PABs as paralleling the overall demand for tax-exempt bonds. Holding risk constant, an investor interested in tax-exempt income is assumed to be indifferent as to whether the security backing the bond is a tax base (general obligation bonds), a quasi-public project (public revenue bonds), or a private firm (PAB).

A second assumption necessary for testing the hypothesis is that states represent the appropriate regions of analysis. Ideally, a test for the yield effects of PABs would focus on the local volume of bond issues and local yields. Unfortunately, such data are not readily available and statewide data must be used in their place.

While individual PAB issues may influence local yields by competing with public use bonds for buyers, they are not large enough by themselves to have more than a marginal influence on statewide yields. Collectively, however, statewide PAB volume will be substantial enough to influence the average yields in the state (as indicated previously, PABs represented over 50 percent of the total tax-exempt bond market between 1983 and 1985). Because the use of PABs (and other tax-exempt debt) is regulated at the state level and varies from state to state, the use of statewide data does not result in a fatal misspecification problem. 
The final assumption is that the statewide volume of public use tax-exempt debt is proportional to state population. The model includes only PAB volume measured on a per capita basis as an indicator of supply, because, as noted, public use volume by state is not known. In a test of the model, it is assumed that independent variations in statewide levels of nonPAB debt are not influencing yields. Given that public use debt is a function of local infrastructure needs, and that these needs are in tum a function of population, the assumption is not unreasonable.

\section{EMPIRICAL RESULTS}

The results of the estimate of Equation (1) are shown in the first column of Table 1. As expected, the change in income and the tax variable are inversely related to yields. The state economy variable (GSP) is significant at the 95 percent level of significance and the tax variable at 90 percent. The regional dummies are also significant, with yields being highest in the West (the reference region). As hypothesized, the per capita level of PAB issues is positively and significantly related to yields. Since the variable is in log form, the impact on yields varies with the level of bond supply. An increase from $\$ 100$ to $\$ 200$ per capita in total issues is associated with a yield increase of 51 basis points, while an increase from $\$ 800$ to $\$ 900$ per capita increases yields by only nine basis points. In all, the model explains about 65 percent of the variation in state tax-exempt bond yields.

As noted above, the average per capita volume of PABs for the period 1983 through 1986 was $\$ 891$. Had the $\$ 150$ per capita cap imposed by the 1984 Tax Act been in effect and applied to all PABs during this entire period, the maximum per capita volume that could have been issued in any one state would have been $\$ 600$. The difference between the yields associated with this volume and the actual average volume of $\$ 891$ would have been approximately 29 basis points.

When using nonlogged values (not reported in Table 1), the estimated coefficient indicates that each $\$ 100$ per capita of PABs resulted in an additional seven basis points in the tax exempt yield. This would imply that the difference in yields associated with an average of $\$ 600$ versus $\$ 891$ of PABs per capita is a little over 20 basis points. It would also imply that, overall, the average per capita PAB volume of $\$ 891$ was associated with average tax-exempt yields being over 62 basis points higher than they would have been in the absence of PAB activity.

The existence of four years of per capita PAB volumes allows for an analysis of the yield impacts over time. Rather than defining the $\mathrm{PAB}$ variable as a fouryear total, Equation (1) is modified to incorporate the annual per capita PAB volume for the years 1983 through 1986 . The results are shown in columns two 
TABLE 1

The Effect of PAB Supply on Tax Exempt Yields

(t- statistics in parentheses)

\begin{tabular}{|c|c|c|c|c|c|}
\hline & 1 & 2 & 3 & 4 & 5 \\
\hline CONSTANT & -0.014 & 1.838 & 2.210 & 1.962 & 4.458 \\
\hline GSP & $\begin{array}{l}-2.973 * \\
(2.18)\end{array}$ & $\begin{array}{l}-2.686 * \\
(2.05)\end{array}$ & $\begin{array}{r}-2.517 \\
(1.78)\end{array}$ & $\begin{array}{l}-3.560 * \\
(2.43)\end{array}$ & $\begin{array}{l}-3.385^{*} \\
(2.15)\end{array}$ \\
\hline TAX & $\begin{array}{r}-0.387 \\
(1.92)\end{array}$ & $\begin{array}{l}-0.392 * \\
(2.03)\end{array}$ & $\begin{array}{l}-0.441 * \\
(2.13)\end{array}$ & $\begin{array}{r}-0.370 \\
(1.72)\end{array}$ & $\begin{array}{l}-0.455 * \\
(2.03)\end{array}$ \\
\hline D NE & $\begin{array}{l}-0.719 * \\
(2.13)\end{array}$ & $\begin{array}{l}-0.518 \\
(1.62)\end{array}$ & $\begin{array}{r}-0.655 \\
(1.90)\end{array}$ & $\begin{array}{r}-0.666 \\
(1.87)\end{array}$ & $\begin{array}{r}-0.597 \\
(1.59)\end{array}$ \\
\hline D MW & $\begin{array}{l}-0.775 * * \\
(2.86)\end{array}$ & $\begin{array}{l}-0.697 * \\
(2.67)\end{array}$ & $\begin{array}{l}-0.745^{*} \\
(2.67)\end{array}$ & $\begin{array}{l}-0.782 * * \\
(2.73)\end{array}$ & $\begin{array}{l}-0.847^{* * *} \\
(2.72)\end{array}$ \\
\hline D S & $\begin{array}{l}-0.555^{*} \\
(2.08)\end{array}$ & $\begin{array}{l}-0.430 \\
(1.69)\end{array}$ & $\begin{array}{l}-0.550 * \\
(2.00)\end{array}$ & $\begin{array}{r}-0.536 \\
(1.90)\end{array}$ & $\begin{array}{r}-0.535 \\
(1.75)\end{array}$ \\
\hline LogPAB & $\begin{array}{l}1.690 * * \\
(3.22)\end{array}$ & & & & \\
\hline LogPAB83 & & $\begin{array}{l}1.339 * * \\
(3.82)\end{array}$ & & & \\
\hline LogPAB84 & & & $\begin{array}{l}1.133^{* *} \\
(2.76)\end{array}$ & & \\
\hline LogPAB 85 & & & & $\begin{array}{l}1.185 * \\
(2.25)\end{array}$ & \\
\hline LogPAB86 & & & & & $\begin{array}{l}0.327 \\
(0.90)\end{array}$ \\
\hline $\mathrm{R}^{2}$ & 0.65 & 0.67 & 0.62 & 0.60 & 0.56 \\
\hline$F$ & 13.21 & 14.83 & 12.19 & 11.21 & 9.65 \\
\hline
\end{tabular}

* 95 percent significance.

** 99 percent significance.

through five of Table 1, with logPAB83 being the log of the state per capita PAB volumes in 1983, etc. The equation is estimated separately for each year, because as the simultaneous inclusion of all years results in a high degree of multicollinearity and distorted estimates.

As shown in Table 1, the coefficients for GSP and the tax and regional dummies remain significant and relatively stable across the estimates. The same ap- 
plies to the coefficients for the PAB variables for 1983 through 1985. As suggested by Hendershott and Kidwell (1978), the impact of bond supplies has lagged the impacts on tax-exempt yields. This result is not surprising, since the current market for tax-exempt bonds will be influenced by existing stocks in investor portfolios. It is surprising, however, that the results here imply that 1983 supplies had the greatest impact on 1986 yields, with the magnitude of the impact declining through 1985.

Interestingly, the coefficient for 1986 is much smaller and not statistically different than zero. Three possible explanations can be offered. First, the supply of tax-exempt bond impacts only yields with a lag time of from one to three years. This conflicts with Hendershott and Kidwell's results, which show that the impact declines monotonically over two quarters. However, the different results may simply stem from the use of cross-sectional annual data versus the use of quarterly time series data.

A second possible explanation for the failure to obtain a significant coefficient for 1986 is the "chaos" in the market that year. On the one hand, because of the tax changes included in the 1986 Tax Act, commercial banks were unloading tax-exempt bonds at a record pace (i.e., the composition of demand was atypical). At the same time the supply of PABs dropped from 50 to 10 percent of the market. The combined state of flux in aggregate supply and demand may have distorted traditional relationships in the short run. Finally, the reduced volume of PABs in 1986 may have resulted in their having too small an impact to influence the level of yields.

\section{SUMMARY AND CONCLUSIONS}

The purpose of the present analysis was to evaluate the relationship between private activity tax-exempt bond supplies in a state and the level of tax-exempt bond yields in that state. Two important conclusions can be drawn from the analysis. First, the results strongly support the theory, advanced by prior authors, that a positive correlation exists between regional bond supplies and tax-exempt bond yields in that region; thus, increased supplies are associated with increased yield levels. This confirms the presence of regional segmentation in the tax-exempt bond market. The relationship was empirically verified for both the stock of supplies issued over a four-year period, as well as for the volume issued in three of the four years examined.

Second, the results substantiate the often-heard criticism that the extensive use of PABs puts upward pressure on tax-exempt borrowing costs for all purposes. In particular, the results obtained in this study indicate that depending on 
the level of PAB volume, each $\$ 100$ per capita of PABs was associated with increases in tax-exempt bond yields in the same state ranging from nine to 51 basis points.

In addition to the impacts on regional yields, increased tax-exempt bond supplies may also have an aggregate impact on the level of tax-exempt yields nationally. ${ }^{6}$ If increased aggregate (national) supplies raise the overall level of tax-exempt yields, a state that chooses to issue a large volume of PABs will pay higher yields itself and shift some costs to other states. If the overall level of yields is not influenced by increased supplies, the state will shoulder the entire cost of higher yields by itself. While the degree of this "cost shifting" remains an important area for further research, the results reported here indicate that PAB finance is not without costs. As trite as it may sound, communities that are currently lobbying for more liberal PAB policies should keep in mind that there are really no free lunches.

\section{ENDNOTES}

1. Actually, "all else" is usually not the same. Tax-exempt financing through the use of municipal bonds also allows for 100 percent financing, the ability to borrow for working capital as well as physical capital, and, prior to 1986, the ability to make short-term arbitrage profits by short-term lending in taxable markets.

2. The reason for this difference has been the subject of an ongoing controversy between those who believe that the tax-exempt bond market is "efficient" and those who believe it is characterized by "preferred habitats." According to the latter view, increased supplies of tax-exempt bonds will require increased yields to clear the market. For a review of these arguments, see Poterba (1989).

3. Beginning in 1983, TEFRA required all PAB issues to be "registered" with the Treasury within one quarter of the bond's issue. As of this date, the Treasury has compiled and released data only through 1986.

4. Commercial bank demand for tax-exempt bonds declined dramatically beginning in 1987 as a result of tax changes included in the Tax Reform Act of 1986. However, as noted previously, the data used here only go through 1986.

5. From a theoretical perspective, the regional dummies are perhaps the weakest variables in the model. Additional estimates were made without them in the model with no significant change in the value or significance of the coefficients of the PAB variables.

6. Nonlogged values of the PAB variable were also used in estimating the equations with similar results. 


\section{REFERENCES}

Campbell, Tim S. "On the Extent of Segmentation in the Municipal Bond Market." Journal of Money, Credit and Banking 12 (1980): 71-83.

Cluff, George S., and Paul G. Farnham. "A Problem of Discrete Choice: Moody's Municipal Bond Ratings." Journal of Economics and Business 37 (1985): 277-302.

Hendershott, Patric H. "Mortgage Revenue Bonds: Tax Exemption with a Vengeance." In Efficiency in the Municipal Bond Market: The Use of Public

Credit for Private Purposes. Edited by George Kaufman. Greenwich, Conn: JAI Press, 1981.

Hendershott, Patric H., and David S. Kidwell. "The Impact of Relative Security Supplies: A Test With Data from a Regional Tax-Exempt Market." Journal of Money, Credit and Banking 10 (1978): 337-46.

Kidwell, David S., Timothy W. Koch, and Duane R. Stock. "The Impact of State Income Taxes on Municipal Borrowing Costs." National Tax Journal 37 (1984): 551-558.

. "Issue Size and Term-Structure Segmentation Effects on Regional Yield Differentials in the Municipal Bond Market." Journal of Economics and Business 39 (1987): 339-347.

Kidwell, David S., and Charles A. Trzcinka. "The Impact of the New York City Fiscal Crisis on the Interest Cost of New Issue Municipal Bonds." Journal of Financial and Quantitative Analysis 18 (1983): 381-399.

Kormendi, Roger C., and Thomas T. Nagle. "The Interest Rate and Tax Revenue Effects of Mortgage Revenue Bonds." In Efficiency in the Municipal Bond Market: The Use of Public Credit for Private Purposes. Edited by George Kaufman. Greenwich, Conn.: JAI Press, 1981.

Leonard, Paul A. "Some Factors Determining Municipal Revenue Bond Interest Costs." Journal of Economics and Business 35 (1983): 71-82.

Marlin, Matthew R. "Rent Seeking and Tax Exempt Finance: Killing the Golden Goose." Policy Studies Journal 17 (1989): 672-688.

Peterson, George E., and Harvey Galper. "Tax Exempt Financing of Private Industry's Pollution Control Investment." Public Policy 23 (1975): 81-102.

Poterba, James M. "Tax Reform and the Market for Tax Exempt Debt." Regional Science and Urban Economics 19 (1989): 537-562.

Renshaw, Vernon, Edward A. Trott, and Howard L. Friedenberg. "Gross State Product by Industry, 1963-86." Survey of Current Business 68 (1988): 30-46. Trzcinka, Charles A. "The Pricing of Tax-Exempt Bonds and the Miller Hypothesis." Journal of Finance 37 (1982): 907-923. 
U.S. Department of the Treasury. Statistics of Income Bulletin. 4 (1984); 5 (1985); 7 (1987); 8 (1988).

Zimmerman, Dennis. The Private Use of Tax-Exempt Bonds. Washington, D.C.: The Urban Institute Press, 1991. 